\title{
Effect of feeding different levels of protein supplementation on the growth performance of young snails (Archachatina marginata) in the western highlands of Cameroon
}

\author{
Ngwarh Perpetua Tuncha, Aziwo Tatanja Niba* and Ndzi Roger Banla \\ Department of Animal Production Technology, College of Technology, University of Bamenda P.O. 39 Bambili, North west region Cameroon
}

\begin{abstract}
This study aimed at improving the growth performance of young snails (Archachatina marginata) fed different levels of protein. This study was carried out between the months of January 2020 to April 2021 at the Helvy Farms-WVED Cameroon located at Station Bamenda. 150 growing snails Archachatina marginata snails weighing between $2.5 \mathrm{~g}$ and $4.5 \mathrm{~g}$, full shells free of any form of injury carefully selected from among the many snails hatched and fed same diets for a period of four weeks before the commencement of the study were monitored for growth performance. These one-month-old snails were randomly allotted to four treatments of different protein levels $(16 \% \mathrm{CP}, 18 \% \mathrm{CP}, 20 \% \mathrm{CP}$ and $22 \% \mathrm{CP}$ ) and a control (natural plant feed) replicated three times with 10 snails each per replicate for a period of 10 months during which data were collected. The snails were monitored daily, watered and fed, the snails in treatments T1, T2, T3, T4 received both the natural plant feed $(30 \mathrm{~g})$ and the formulated diet $(30 \mathrm{~g})$ meanwhile, the snails in the control received $60 \mathrm{~g}$ of the natural plant feed daily. At the beginning of the trials and after every two weeks, the snails were weighed with a $0.01 \mathrm{~g}$ precision balance and the shell lengths and widths taken using a vernier caliper of $0.02 \mathrm{~mm}$ accuracy. The results showed that, average weight gain $(39.17 \pm 1.45 \mathrm{~g})$, average feed intake $(42.54 \pm 1.65 \mathrm{~g})$, percentage survival $(90.00 \pm 0.00)$, shell length gain $(7.66 \pm 1.45 \mathrm{~cm})$ shell weight gain $(5.73 \pm 0.96 \mathrm{~cm})$ were significantly higher $(\mathrm{P}<0.05)$ in snails fed $22 \%$ protein. We can therefore recommend that $22 \% \mathrm{CP}$ be included in the diet of Archachatina marginata breeding snails for better growth performance.
\end{abstract}

\section{Introduction}

The demand for animal protein supplies has been on a continuous increase in recent years in most developing countries as a whole and in Cameroon in particular. This high demand has fast outstripped supplies. The inadequacy in the available protein production and the high cost available animal protein sources has put protein of animal origin out of reach for an average Cameroonian. There is need to diversify livestock production with emphasis on non-conventional livestock production [1], in order to address the problems of inadequate protein supply to the average Cameroonian.

FAO statistics of 2013 reported that animal protein consumption in Cameroon constitutes only about $51.96 \mathrm{~g} /$ capita/day far below the recommended $81.23 \mathrm{~g} / \mathrm{Capital} / \mathrm{day}$ by FAO [2]. This low average daily intake suggests adverse consequences in the area of health, production and development among human society with children and breast feeding mothers $[3,4]$ attributed the inadequate supply and consumption of animal protein in Cameroon to be the reliance on traditional methods of breeding conventional livestock species such as cattle, small ruminants, pigs, poultry etc. and these cannot satisfy the high protein demand with the rising population in Cameroon. The traditional husbandry systems are characterized by low-input-highcost of feed, high disease prevalence rate and low productivity.

Over the years, efforts have been targeted towards alternative feed resources that could maintain and/or improve the nutritive value of individual animals in order to sustain the livestock sector in Cameroon.
The quality of the outcome of any production venture depends on the quality of its inputs as such, the growth performance of snails is greatly influenced by what the snails feed on [5-8].

Protein is considered as the dietary component that evokes the widest array of complex scientific, economic and environmental issues. It is the most expensive component of supplemental feed. In the wild and also in most extensive snail farming ventures, only natural plant food materials are considered as feed [7-9]. These feeds according to Kehinde et al. [6] and Odunaiya et al. [10], are seasonal, perishable and cannot supply all the nutrients required for optimum growth performance of snails. Although snails can subsist on legumes, fruits, kitchen leftovers and forages that do not compete with human diets, the growth performances recorded through feeding young snails (Archachatina marginata) on plant materials supplemented with formulated diets was significantly higher than that obtained through feeding with only plant food materials [11-13]. There is therefore need to use complete balanced formulated feeds as supplemental diet for a

${ }^{\star}$ Correspondence to: Aziwo Tatanja Niba, Department of Animal Production Technology, College of Technology, University of Bamenda P.O. 39 Bambili, North west region Cameroon, Tel: 0023679498574; Email: aziwoniba2016@gmail.com

Key words: Archachatina marginata, growth performance, formulated diet, young snails

Received: April 16, 2021; Accepted: April 23, 2021; Published: April 30, 2021 
Tuncha NP (2021) Effect of feeding different levels of protein supplementation on the growth performance of young snails (Archachatina marginata) in the western highlands of Cameroon

timely and successful snail production venture since their performance is greatly influenced by what the snails feed on [5-8]. This study was therefore designed to investigate the effect of different levels of protein on the growth performance of Giant African Land Snail (Archachtina marginata) in the Western Highlands of Cameroon.

\section{Materials and methods}

\section{Study period and area}

This study was carried out between April 2020 to January 2021 (10months) under controlled climatic conditions at the snailery unit of Helvy farms upskill Research at Station Bamenda of the Western Highlands of Cameroon, situated on latitude $5^{\circ} 57^{\prime} 5.98^{\prime \prime}$ $\mathrm{N}$ and longitude $10^{\circ} 10^{\prime} 1.04^{\prime \prime} \mathrm{E}$, at an altitude of $1,258 \mathrm{~m}$ above sea level (Google maps). The area is located in the Western highlands according to the agro ecological zones of Cameroon and characterized by a tropical climate consisting of two distinct seasons, a wet season running from March to October and a dry season going from November to February. The mean annual rainfall stands at $2,145 \mathrm{~mm}$ and a mean annual temperature of $21.5^{\circ} \mathrm{C}$ with the highest temperatures recorded in March $\left(23^{\circ} \mathrm{C}\right)$ and the lowest temperatures recorded in the months of July and August. The average relative humidity stands at $75 \%$ with February recording the lowest mean relative humidity and July being the most humid month.

\section{Experimental design and experimental diet}

The study was conducted following a completely randomized design with four treatments plus a control each replicated three times. 150 young snails monitored for a period of one month before commencement of the trial and weighing between $2.50 \pm 1.00 \mathrm{~g}$ to $4.50 \pm 1.00 \mathrm{~g}$ born from breeding snails derived from the snailery, were randomly allotted to four treatments [T1 $(16 \% \mathrm{CP}), \mathrm{T} 2(18 \% \mathrm{CP}), \mathrm{T} 3(20 \% \mathrm{CP}), \mathrm{T} 4(22 \% \mathrm{CP})]$ + a control [T5 (plant food materials)]. Each treatment was allotted 30snails with 10 each per replicate which were placed in their respective pens and monitored for growth traits. The experimental diet is as on Table 1 and the experimental design as on Figure 1.

Table 1. Feed formula and chemical composition of experimental diets/ration

\begin{tabular}{|c|c|c|c|c|}
\hline \multirow{2}{*}{ Ingredients } & \multicolumn{4}{|c|}{ Proportion of Ingredients (\%) } \\
\hline & T1 (16\%) & $\mathrm{T} 2(18 \%)$ & T3 (20\%) & T4 (22\%) \\
\hline Corn flour & 55.00 & 50.5 & 47.0 & 41.9 \\
\hline Soybean cake $(49 \%)$ & 16.8 & 17.4 & 14.0 & 16.0 \\
\hline Palm kernel cake & 2.4 & 2.4 & 2.2 & 2.0 \\
\hline Fish meal $(60 \%)$ & 5.7 & 9.6 & 16.7 & 20.0 \\
\hline Limestone $(\mathrm{CaCO} 3) 40 \%$ & 20.0 & 20.0 & 20.0 & 20.0 \\
\hline Iodized salt & 0.1 & 0.1 & 0.1 & 0.1 \\
\hline Total & 100 & 100 & 100 & 100 \\
\hline \multicolumn{5}{|c|}{ Calculated Bromatological Composition } \\
\hline Crude Protein (\%DM) & 16.0 & 18.0 & 20.0 & 22.0 \\
\hline Calcium & 7.8 & 7.9 & 8.15 & 8.3 \\
\hline ME (Kcal/KgDM) & 2439 & 2429 & 2451 & 2433 \\
\hline Lysine & 0.85 & 1.03 & 1.24 & 1.4 \\
\hline Phosphorus & 0.3 & 0.37 & 0.5 & 0.6 \\
\hline Methronine & 0.33 & 0.4 & 0.5 & 0.6 \\
\hline Fat & 3.4 & 3.7 & 4.25 & 4.5 \\
\hline
\end{tabular}

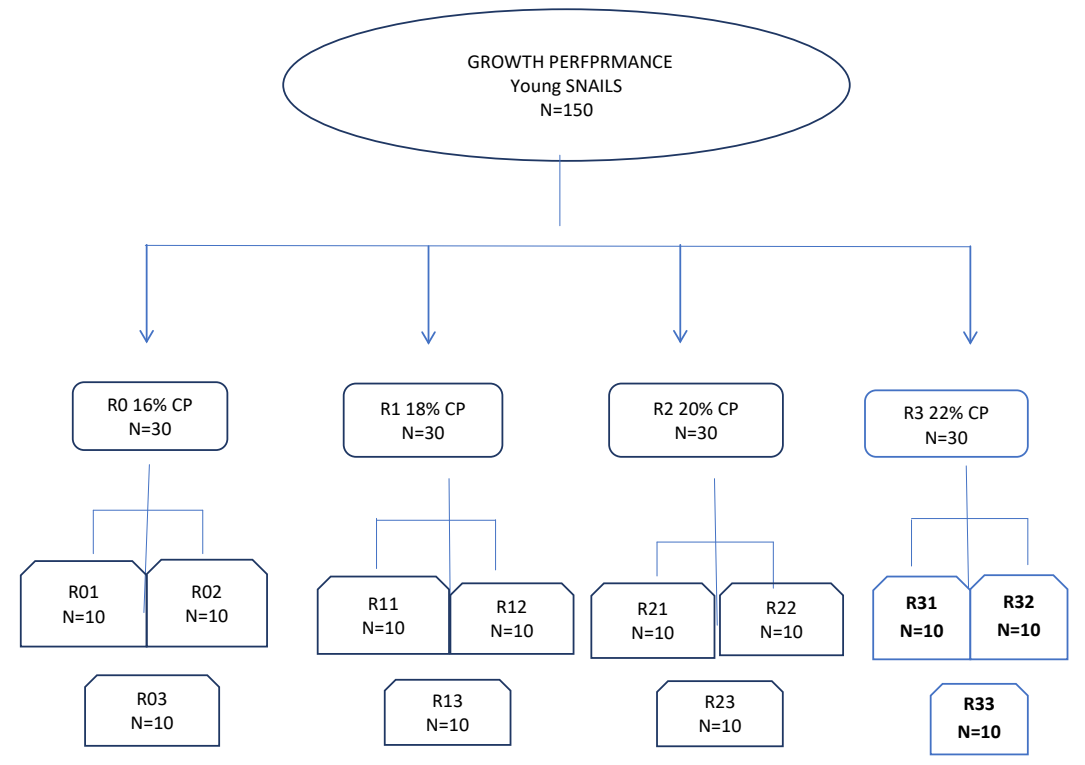

Figure 1: Experimental Design for growth performance. $\#$ control $N=30$ 
Tuncha NP (2021) Effect of feeding different levels of protein supplementation on the growth performance of young snails (Archachatina marginata) in the western highlands of Cameroon

\section{Animal management}

The 150 young Archachatina marginata snails used for this study were carefully selected out of a multitude of hatchlings, weighed and monitored for a period of one month after hatching. At the one month of age, snails that were below $2.50 \mathrm{~g}$ were not selected for the study. The Archachatina marginata snails were managed intensively in built up surface trench pens of $1 \mathrm{~m} \times 0.5$ $\mathrm{m} \times 0.5 \mathrm{~m}$ in dimension under a shade made of aluminum roofing sheets in an open space with adequate cross ventilation. The pens were filled with previously heat-treated soil up to about $20 \mathrm{~cm}$ deep. Treated dry leaves of banana (Musa paradisiaca) were orderly placed in each pen to serve for covering, moisture absorber and for food. Shallow Feeding and drinking troughs were placed in all pens.

Each pen of T1 T2 T3 and T4 received 30g of formulated diets containing different levels of protein $(16 \%, 18 \%, 20 \%$ and $22 \%)+$ a basal plant diet ( $30 \mathrm{~g})$ while the snails in the Control (T5) pen received only the basal plant food diet $(60 \mathrm{~g})$ daily. The basal plant diet was weighed before feeding and it was made of pawpaw leaves, plantain leaves, pawpaw fruits, watermelon, ripe bananas and plantains, cabbage and waterleaf used throughout the experiment. Water was provided ad libitum, snails were fed each day between $4-5 \mathrm{pm}$. The snail pens were also watered every day to maintain the required humidity level for snail growth.

\section{Data collection}

Data were recorded on various growth performance characteristics (weight gain, feed intake, feed conversion ratio, shell length, shell width, shell diameter, survival rate and mortality). The snails were weighed at the beginning of the trial and after every two weeks that is twice each month throughout the 10 months using a KA8-AM digital LCD electronic scale balance of $0.01 \mathrm{~g}$ sensitivity and weights recorded. The morphometric characteristics of the shell (length, width) were also measured using a Carbon Steel vernier caliper of $0.02 \mathrm{~mm}$ accuracy. Pens were checked daily for dead snails and mortality recorded. The following formulae were used to calculate the growth parameters;

\section{Growth parameters calculated}

» Weight gain (WG)

$\mathrm{WG}=$ Final weight - Initial weight

- Average daily weight gain (ADWG)

$$
A D W G=\frac{\text { weight gain }}{\text { duration of the experiment }}
$$

Feed Intake (FI)

FI= Quantity of feed distributed - Remnants

» Feed conversion Ratio (FCR)

$$
F C R=\frac{\text { total quantiy of feed consumed }}{\text { total weight of the snail }}
$$

»Shell length gain (SLG), and shell width gain (SWG)

$$
\mathrm{SLG}=\text { Final length }- \text { Initial length }
$$

$\mathrm{SWG}=$ Final shell width - Initial shell width

» Percentage Survival Rate (SR) and Percentage Mortality

$$
\text { Percentage mortality }=\frac{\text { number of deaths }}{\text { total number of snails }} \times 100
$$

- Survival rate $\%(\mathrm{SR})$

$$
\begin{aligned}
& S R \%=(N S-D S) \times \frac{100}{N S} \\
& N S=\text { total number of snails } \\
& D S=\text { total number of dead snails }
\end{aligned}
$$

Formulae adapted from [14]

\section{Data analyses}

Data collected were subjected to a one way Analysis Of Variance-ANOVA (variable being protein level) following the general linear model (GLM). Separation of significant means was done using Waller Duncan's Test (Duncan) [15] at 5\% significance rate (Steel and Torrie). [16] Correlation and regression coefficients were used to evaluate the relationship between protein level and weight gain and morphometric characteristics of the shell. Statistical Analyses were done using of SPSS 18.0. The experimental model is as follows;

$$
\begin{aligned}
& \mathbf{X}_{\mathrm{ij}}=\boldsymbol{\mu}+\boldsymbol{\alpha}_{\mathrm{i}}+\mathrm{e}_{\mathrm{ij}} \\
& \mathrm{X}_{\mathrm{ij}}=\text { Observation on the animal having received treatment or } \\
& \mu=\text { general mean } \\
& \alpha_{i}=\text { Effect of protein level (i) } \\
& e_{i j}=\text { residual error caused by animal } j \text { having received the }
\end{aligned}
$$
ration $\mathrm{i}$ treatment or ration $\mathrm{i}$

\section{Results}

Effect of protein levels on weight gain, feed intake, feed conversion ratio and percentage survival in young snails

Apart from Feed conversion ratio, weight gain, feed intake and percentage survival were significantly $(\mathrm{P}<0.05)$ higher in snails fed $22 \%$ CP compared to the control. However, did not show any significant difference $(\mathrm{P}>0.05)$ with other treatments (Table 2$)$.

\section{Effect of protein levels on morphometric characteristics of} the shell (shell length and shell width)

From Table 3, all the shell characteristics were comparable $(\mathrm{P}>0.05)$ among groups of snails fed with different protein level. Nevertheless, those receiving $22 \%$ protein level showed significantly $(\mathrm{P}<0.05)$ high values of shell characteristics compared to the control.

Effect of protein levels on the evolution of weight gain in young snails

Weight gain increased significantly $(\mathrm{P}>0.05)$ in snails fed $22 \%$ protein compared to those fed the natural plants food in the control experiment (Figure 2). There was a positive strong correlation $(\mathrm{P}<0.01)$ witnessed between protein levels and weight gain in young snails $\left(\mathrm{r}^{2}=0.98\right)$. 
Tuncha NP (2021) Effect of feeding different levels of protein supplementation on the growth performance of young snails (Archachatina marginata) in the western highlands of Cameroon

Table 2. Effect of protein levels on weight gain, feed intake, feed conversion ratio and percentage survival in young snails.

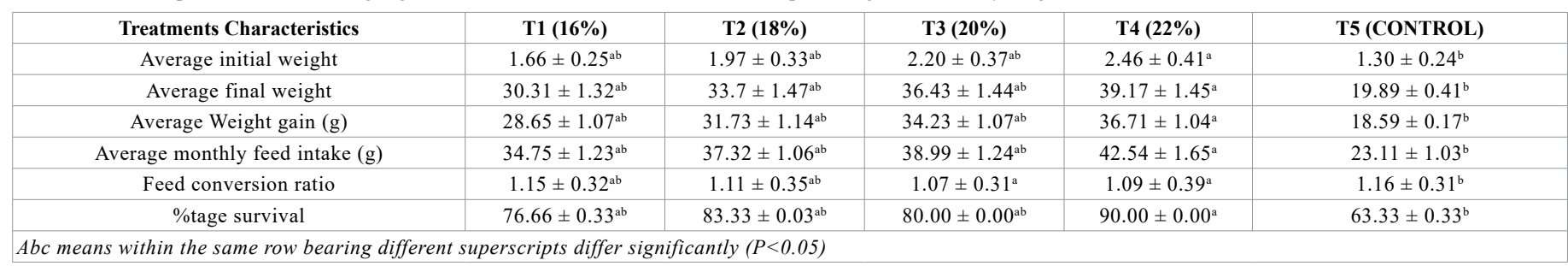

Table 3. Effect of protein levels on morphometric characteristics of the shell (shell length, shell width and shell diameter).

\begin{tabular}{|l|c|c|c|c|}
\hline Treatments Shell characteristics & T1 (16\%) & T2 (18\%) & T3 (20\%) & T4 (22\%) \\
\hline Average initial shell length (cm) & $0.65 \pm 0.11^{\mathrm{ab}}$ & $0.77 \pm 0.21^{\mathrm{ab}}$ & $0.81 \pm 0.03^{\mathrm{ab}}$ & $0.99 \pm 0.32^{\mathrm{a}}$ \\
\hline Final shell length (cm) & $7.1 \pm 0.23^{\mathrm{ab}}$ & $7.64 \pm 0.25^{\mathrm{ab}}$ & $7.84 \pm 0.23^{\mathrm{ab}}$ & $0.42 \pm 0.01^{\mathrm{b}}$ \\
\hline Shell length gain & $6.45 \pm 1.12^{\mathrm{ab}}$ & $6.87 \pm 1.32^{\mathrm{ab}}$ & $7.03 \pm 1.25^{\mathrm{a}}$ & $7.97 \pm 0.17^{\mathrm{b}}$ \\
\hline Average initial shell width (cm) & $0.41 \pm 0.21^{\mathrm{ab}}$ & $0.52 \pm 0.22^{\mathrm{ab}}$ & $0.63 \pm 0.11^{\mathrm{ab}}$ & $0.29^{\mathrm{a}}$ \\
\hline Final shell width (cm) & $5.06 \pm 0.22^{\mathrm{ab}}$ & $5.59 \pm 0.25^{\mathrm{ab}}$ & $5.75 \pm 0.24^{\mathrm{ab}}$ & $6.51 \pm 0.22^{\mathrm{a}}$ \\
\hline Shell width gain & $4.65 \pm 0.74^{\mathrm{ab}}$ & $5.07 \pm 0.79^{\mathrm{ab}}$ & $5.12 \pm 0.87^{\mathrm{ab}}$ & $5.73 \pm 0.96^{\mathrm{a}}$ \\
\hline Abc means within the same row bearing different superscripts differ significantly $(P<0.05)$. & $3.76 \pm 0.13^{\mathrm{b}}$ & $3.47 \pm 0.65^{\mathrm{b}}$ \\
\hline
\end{tabular}

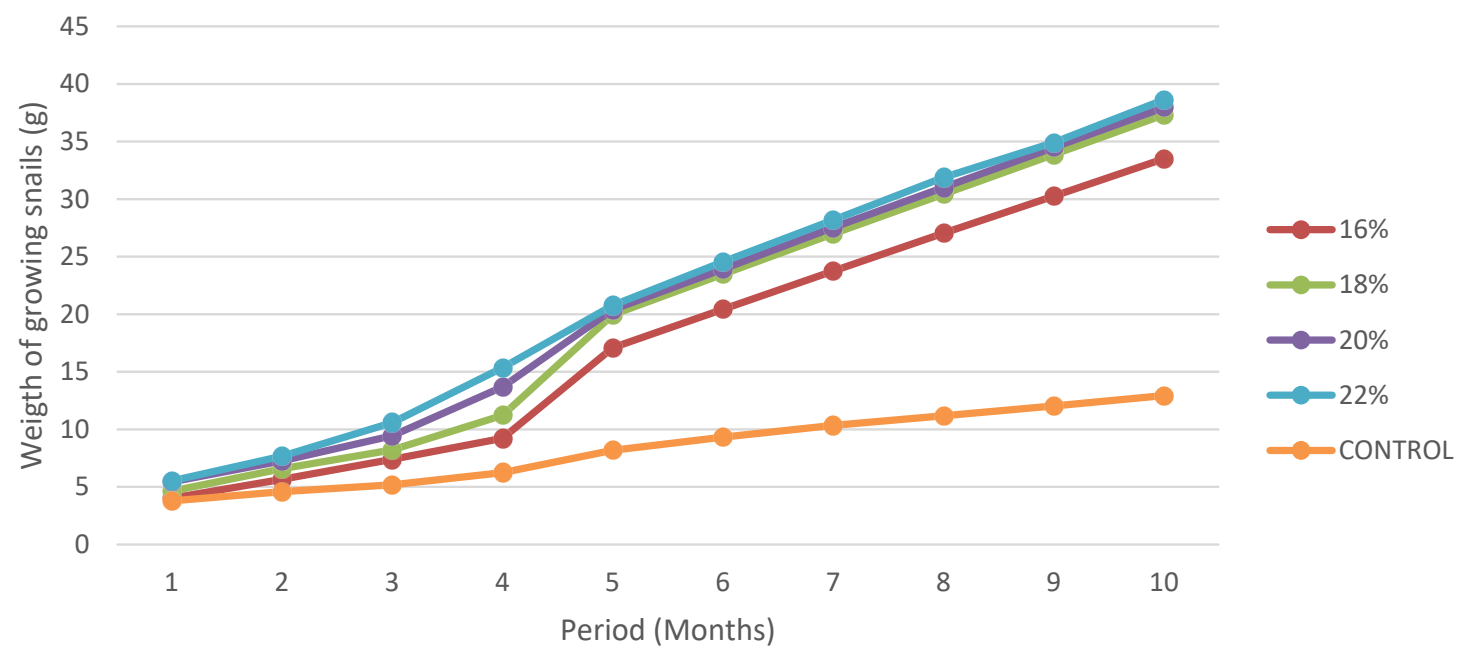

Figure 2. Evolution of weight gain with respect to protein levels in young snails

\section{Effect of protein levels on the evolution of snail shell length gain}

Figure 3 illustrates shell length gain with respect to the level of protein fed in the diet. A negative and strong correlation was observed between Shell length gain and protein levels/control experiment $\left(r^{2}=-0.24\right)$. It was observed that there exists a positive and strong correlation $\left(\mathrm{r}^{2}=0.29\right)$ between shell length and weight gain in young snails. The snails fed $20 \%$ and $22 \%$ protein level showed a significantly higher $(\mathrm{P}>0.05)$ shell length gain than those of $16 \%$ and $18 \%$ while those in the control experiment were significantly lower $(\mathrm{P}<0.05)$.

\section{Effect of protein levels on the evolution of snail shell width gain}

In Figure 4, it was observed that the shell width increased in all the treatments, with highest coming from snails fed $22 \%$ protein level and the lowest from snails fed the control diet. Meanwhile, snails fed $18 \%$ and $20 \%$ also experienced a significant high increase in shell width. A positive and strong correlation was observed between weight gain and shell width $\left(r^{2}=0.27\right)$. Meanwhile, a negative and strong correlation was observed between protein level and shell width $\left(r^{2}=-0.24\right)$.

\section{Discussion}

The findings of this study revealed a substantial increase in weight gain, feed intake, feed conversion ratio, shell length, shell width and percentage survival of young snails. The growth performance of the snails fed the experimental feed at different protein levels was better than the snails fed natural plant feed. This reveals that protein plays a significant role in the growth of Giant African Land Snails (Archachatina marginata).

The snails fed $22 \%$ protein were significantly higher $(\mathrm{P}<0.05)$ in weight gain, feed intake and percentage survival but significantly lower $(\mathrm{P}>0.05)$ in feed conversion ratio due to efficient utilization of the feed nutrients. This explains the fact that Giant African land Snails utilize nutrients available in the formulated diets more efficiently. Those fed $16 \%, 18 \%$ and $20 \%$ protein did not differ significantly $(\mathrm{P} \geq 0.05)$. Meanwhile, snails 
Tuncha NP (2021) Effect of feeding different levels of protein supplementation on the growth performance of young snails (Archachatina marginata) in the western highlands of Cameroon

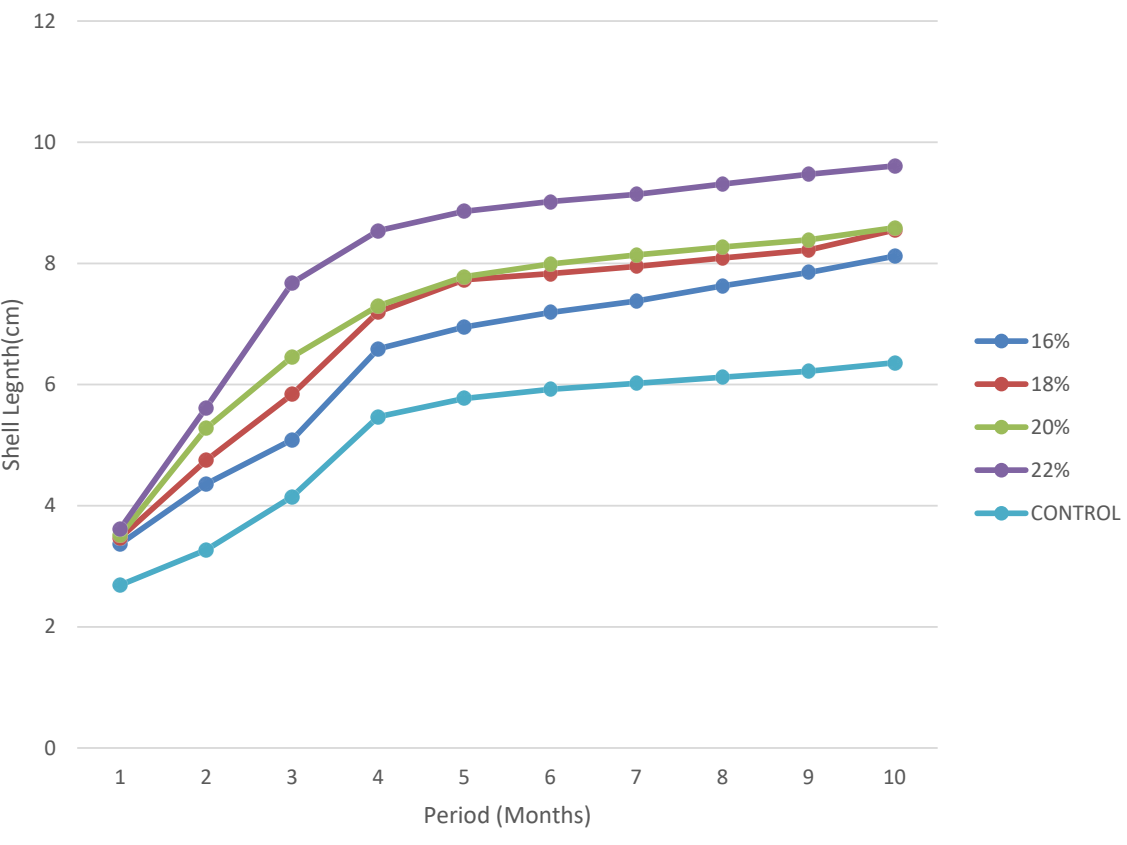

Figure 3. Evolution of shell length with respect to protein levels in young snails

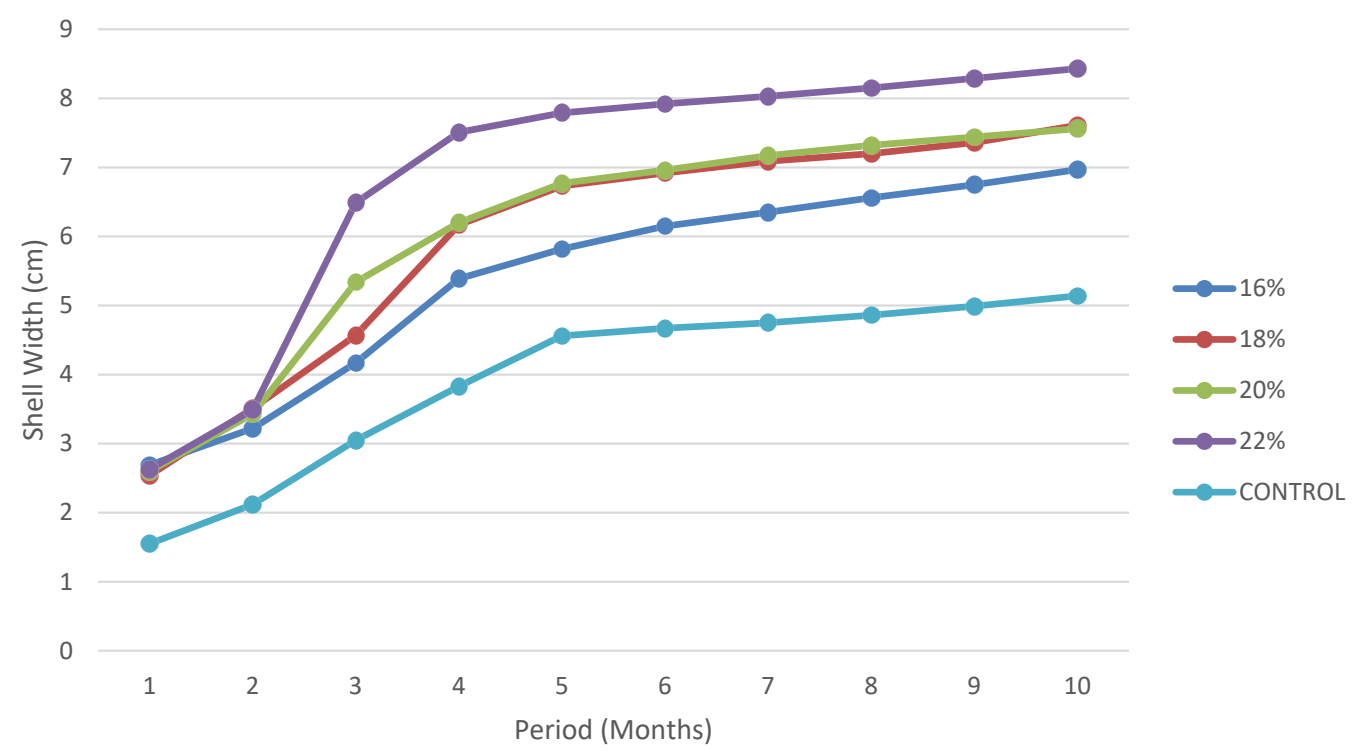

Figure 4. Evolution of shell width with respect to protein levels in young snails

fed the control diet were significantly lower $(\mathrm{P}>0.05)$ in in weight gain, feed intake and percentage survival but significantly higher $(\mathrm{P}<0.05)$ in feed conversion ratio. These findings show that food consumption increased with increase in protein levels. These results are similar to those of Augustine et al. [17], Amusan et al. [18], Ani et al. [19], Eshiett et al. [20] who found out that the final body weight gain of snails were improved as the dietary protein increased to $22 \%$. This also agrees with the findings of Eshiett et al. [20], Jensen et al. [21], Calderon et al. [22] who found that the weight gain of grower rabbits was significantly improved as the dietary protein level increased and also, the effect of protein level on breeding and growth performance of hens and reported that food consumption increases with increasing protein levels in the diet respectively. Omole et al. [12] and Sang-Min et al. [23] found out that a formulated diet containing $22 \%$ and $28 \%$ protein are needed to optimize the growth performance of juvenile snails (Semisulcospira gottscheri). These findings are also at variance with the value of feeding snails with $18 \% \mathrm{CP}$ reported by Adu et al. [24] for Archachatina marginata growing snails. Also, crude protein levels of $18.15 \%, 24.28 \%$ and $25 \%$ had been used by Adeyemo et al. [26] and Stievenart [11], Ejidike et al. [27] respectively to show similar influence on growth performance of snails. The reason why snails fed formulated diets perform better could be likened to the fact that these diets comprise of different ingredients in balanced 
Tuncha NP (2021) Effect of feeding different levels of protein supplementation on the growth performance of young snails (Archachatina marginata) in the western highlands of Cameroon

proportions originating from different feedstuffs. This could also be explained by the fact that increased levels of protein in the diet stimulate appetite in young snails whose feed intake, weight gain and survival would be greatly influenced.

Our results revealed appreciable higher values of shell length and shell width in snails fed $22 \%$ protein. The values obtained were higher than those of Augustine et al. [17] and Omole et al. [12], who respectively reported shell length and shell width values of 3.6$4.13 \mathrm{~cm}$ for 16 weeks Archachatina marginata, $0.75 \mathrm{~cm}$ for $6 \mathrm{months}$ old Achatina achatina. Also, Tchowan et al. [14] and Akinnusi [28] who respectively worked on the effect of protein and energy on the growth performance of snails (Achatina achatina) and Oluokun et al. [29] who worked on the effect of calcium supplementation on growth characteristics Archachatina marginata and showed that a diet of $24 \%$ protein and $8 \%$ of calcium is needed for the growth of young snails. The growth in the body tissues and shell signifies weight gain in snails both of which are influenced by the nutritive value of the feed especially protein. The optimum protein level for shell length and shell width of $22 \%$ as obtained in this study is comparable with that reported by Tchowan GM, et al. [14], Augustine et al. [17], Mai et al. [30], Uki et al. [31].

\section{Conclusion}

The growth response obtained by snails fed the dietary protein level of $22 \%$ for 11 months greatly improves feed intake, weight gain, shell length, shell width and survival. So, it can be concluded that $22 \%$ protein level is optimum for the growth of young snails and can be retained in the diet of growing snails.

\section{References}

1. Ani AO, Adiegwu LI (2005) The feeding value of velvet beans (Mucuna pruriens) to weaner rabbits. Proc. $30^{\text {th }}$ Ann. Conf. of Nig. Soc. For Anim. Prod. (NSAP), 20 th $-24^{\text {th }}$ March 2005. University of Nigeria, Nsukka, Nigeria. pp: 186-189.

2. FAO (2013) Improved Snail Farming. Farmer Level Tech. Notes.

3. Agwunobi LN, Ina-Ibor OB (2007) Processed rubber seed meal in the diets of growing Japanese quails (Coturnix coturnix japonica), proceedings of the $32^{\text {nd }}$ Animal Conference of the Nigerian Society for Animal Production. University of Calabar, Nigeria. pp: 386-3883.

4. Labonne M, Magrong P, Oustalet Y (2003) Le secteur de l'elevage au Cameroun et dans les Provinces du Grand Nord: situation actuelle, contraintes, enjeux et defis, Cirad, Prasac. Inc. pp: 12.

5. Okonkwo AC, Isaac LJ, Nkanga I, usoro OO (2000) Effect of various feeding regimes on the performance of snails (Archachatina marginata). Proc $25^{\text {th }}$ Ann. Conf. Nig. Soc. For Anim Prod (NSAP), March 19-23,2000. Michael Okpara Univ. of Agric. Umudike, Nigeria. pp: $314-315$

6. Kehinde AS, Omole AJ, Odidi SE, Muraina G, Ayoola OA, et al. (2004) Effect of different protein levels on the performance of growing snails. J Agricul For Soc Sci 2: $78-83$.

7. Akinnusi $\mathrm{O}$ (2004) Introduction to snail farming. ( $2^{\text {nd }}$ edn $)$, Abeokuta:bTriolas Esquisite Ventures. pp: 42-44.

8. Okon B, Ibom LA, Williams ME, Etukudo OM (2010) Effects of parity on breeding and morphometric traits of eggs and hatchlings of F1 crossbred of snails (Archachatina marginata var. saturalis). J Agricul Biotech Ecol 3: 36-43.

9. Okon, B, Ibom LA (2012) Snail breeding and snailery management. Freshdew Productions, Calabar. pp: 1-70.
10. Odunaiya O, Akinnusi FAO (2008) Effect of some cheap locally available feeding material on the growth performance of edible land snail. Proc $33^{\text {rd }}$ Ann. Conf. of Nig. Soc. for Anim. Prod. (NSAP). March $16^{\text {th }}-20^{\text {th }}, 2008$, College of Agricultural Sciences, Olabisi Onabanjo University, Yewa Campus, Ayetoro, Ogun State Nigeria. pp: $126-128$.

11. Stievenart C (1992) Observation on shell lip formation and reproduction in the giant African land snail (A. marginata). Snail Farming Res 4: 20-29.

12. Omole AJ, Tewe OO, Makinde GO, Adetoro FO, Saka JO, et al. (2000) Preliminary studies on the response of growing snails (A. marginata) to compounded feed as a supplementary ration. Trop Anim 3: 35-40.

13. Ejidike BN (2001) Comparative effect of supplemental and complete diets on the performance of African giant land snail (Archachatina marginata). Proceedings of the 26th Annual Conference of the Nigerian Society for Animal Production 26: 151-153.

14. Tchowan GM, Ngoula F, Kenfack A, Tchoumboue J (2018) Effects of protein levels on the growth performance of Giant African land Snails (Achatina achatina) in captivity.

15. Duncan DB (1955) New Multiple Range Test. Biometrics 11: 1-42.

16. Steel RGD, Torrie JH (1980) Principles and procedures of statistics. A biometric approach. ( $\left.2^{\text {nd }} \mathrm{edn}\right), \mathrm{McGraw}-\mathrm{Hill}$, New York (NY), USA.

17. Augustine O, Ani, Leonard CU (2011) Effect of different protein levels on the growth performance of African Giant Land Snail (Achatina achatina) fed soybean meal based diets. Global J Agricul Sci 10: 151-155.

18. Amusan JA, Omidiji MO (1998) Edible land snails. A technical guide to snail farming in the tropics. Verity Printers Ibadan. pp: 60.

19. Ani AO, Ogbu CC, Elufidipe CO, Ugwuowo LC (2013) Growth performance of African giant land snail (Achatina achatina) fed varying dietary protein and energy levels. J Agricul Biol Sci 8: 184-190.

20. Eshiett NO, Omole TA, Oluyemi JA (1979) The crude protein and energy requirements of rabbits in the tropics. Nig J Agric Sci 1: 113-117.

21. Jensen LS, Calderon VM, Mendonca JR (1990) Response to tryptophane of laying hens fed practical diet varying in protein concentration. Poultry sci 69: 1965-1965.

22. Calderon VM, Jensen LSP (1990). The requirement for sulfur amino acid by laying hens as influenced by the concentration. Poultry sci 69: 934-944.

23. Sang-Min L, Tae-Jun L (2005) Effects of dietary protein and energy on growth and lipid composition of juvenile snails. J Shellfish Res 24: 99-102.

24. Adu OA, Ojurongbe AO, Omole AJ (2002) Proc. $27^{\text {th }}$ Conf., Nig. Soc. for Anim. Prod (NSAP). March 17-21, 2002, Fed. Univ. of Tech., Akure, Nigeria. pp: 325-327.

25. Adeyemo AI, Borire OF (2002) Response of giant land snail (Archachatina marginata) to graded levels of yam peel meal-based diets. Proc. $27^{\text {th }}$ Ann. Conf. Nig. Soc. for Anim. Prod. (NSAP). March 12-21, 2002. Federal Univ. of Tech. Akure, Nigeria. pp: 335-336.

26. Adeyemo AI, Akeredolu KE (2002) Performance of African Giant Snail (Archachatina marginata) on different feed items. Proc $27^{\text {th }}$ Ann. Conf. Nig. Soc. for Anim. Prod. (NSAP). March 12-21,2002. Federal Univ. of Tech. Akure, Nigeria. pp: 338-339.

27. Ejidike BN, Afolayan TA, Alokan JA (2004) Observations on some climatic variables and dietary influence on the performance of cultivated African giant land snail (Archachatina marginata): Notes and records. Parkistan J Nutri 3: 362-364.

28. Akinnusi FAO (2002) Comparative evaluation of fresh fruits leaves and concentrate feed on the growth and reproductive performance of the African giant snail (Archachatina marginata). Proceedings of the $27^{\text {th }}$ Annual Conference of Nigeria Society for Animal production (NSAP). pp: 328-330.

29. Oluokun JA, Omole AJ, Fapouanda O (2005) Effect of increasing the level of calcium supplementation in the diets of growing snail on performance characteristics. Res $J$ Agricul Biol Sci 1: 76-79.

30. Mai K, Mercer JP, Donton J (1995) Comparative studies on the nutrition of two species of abalone. Aquaculture 136: 165-180.

31. Uki NA, Kemuyama, Watanabe Y (1986) Optimum protein levels in diets for abalone. Bull Jpn soc Sci Fish 52: 1005-1012.

Copyright: $(02021$ Tuncha NP. This is an open-access article distributed under the terms of the Creative Commons Attribution License, which permits unrestricted use, distribution, and reproduction in any medium, provided the original author and source are credited. 